\title{
Banking Industry Regulation and Strategic Action Fields: a research agenda for Economic Sociology
}

\author{
Manuel Ángel Santana Turégano \\ Universidad de La Laguna \\ masantur@ull.es
}

Resumen: el artículo examina la evolución de la regulación de la banca en la UE tras la crisis financiera global de 2008. Propone analizar el sector como un campo de acción estratégico, incrustado en una red de campos en que los agentes difieren en su poder y capacidad de influencia. El análisis se centra en dos politicas implementadas bajo la nueva regulación europea, la limitación de la remuneración variable y la introducción de cuotas de diversidad. Sigue el mecanismo de elaboración de políticas, desde la discusión cientifica acerca de si estas medidas mejoran el rendimiento de las organizaciones hasta la adopción de políticas de politicas que encierran todas las controversias en una caja negra. Esta indagación, aunque modesta, sugiere que se podría obtener un mejor conocimiento de la regulación bancaria a través de un enfoque que combine la teoría de los campos de acción estratégico y los estudios sociales de la ciencia.

Palabras clave: gobierno corporativo, estudios sociales de la ciencia, Unión Europea, crisis financiera de 2008.

Abstract: This paper examines the evolution of the regulation of the banking industry in the EU after the global financial crisis of 2008. It proposes to analyze the sector as a strategic action field, embedded in a web of fields and where participants differ in their power and influence. The analysis focuses on two policies implemented under the new European regulation: the limitation of variable remuneration and the introduction of diversity quotas. It uses ideas developed by Social Studies of Science (SSS) to monitor the policy-making 
mechanism, from the scientific discussion about whether these measures improve the performance of organizations to the adoption of policies that close all controversies in a black box. This inquiry, albeit modest, suggests that a deeper understanding of the regulation of the banking industry could be gained by following an approach that combines Strategic Action Fields Theory and Social Studies of Science.

Key Words: corporate governance, social studies of science, European Union, 2008 financial crisis. 


\section{Introduction}

Since the global financial crisis of 2008-8 the strategic field of the banking industry has experienced major upheavals. In the year 2013 a new regulation of the European sector was enacted, consisting of Directive 2013/36/EU "on access to the activity of credit institutions and the prudential supervision of credit institutions" and Regulation 575/2013, which develops it. The whole package has become known as the CRDIV (The Fourth Capital Requirement Directive) and introduces important changes in the rules governing the field, especially in the realm of corporate governance of banks. How are banks organized? What are the social causes and consequences of the changes in the organization of banks? These are the issues that this paper will deal with, bearing in mind that finance in modern societies is no longer an individual field but a transversal domain that impacts on each and every aspect of society, to the extent that it has become common to speak about the financialization of society. The institutional regulation of any given economic sector is a key issue that strongly influences how the sector, and any specific firm within it, is organized. The specificity of the banking sector is that, given the key role it plays in modern economies, it is more tightly regulated than others. Therefore, to a great extent, the organization of the banking sector is the result of institutional regulation, not only a matter of hard, objective economic performance but also of soft, subjective, social equilibria.

The aim of this paper is to provide a brief overview of how the banking regulation in the EU can be studied using strategic action fields. These can be defined as "a meso-level social order where actors (...) interact with knowledge of one another under a set of common understandings about the purposes of the field, the relationships in the field (...), and the field's rules" (Fligstein \& McAdam, 2011:3). The boundaries of any field are not fixed, but can change depending on the definition of the situation and the issues at stake (the "banking industry" might or might not include saving unions and insurance companies depending on the definition of the situation). Any strategic action field (SAF) includes incumbents, challengers and governance units. Incumbents are "actors who wield disproportionate influence within a field and whose interests and views tend to be heavily reflected in the dominant organization of the Strategic Action Field (SAF)" (Fligstein \& McAdam, 2011:5). As we will see, the present regulation of the banking industry reflects the strong influence that some actors have over it. Challengers, on the other hand, are those actors who occupy less privileged positions, but who nevertheless conform to the prevailing order, taking what the system gives them and awaiting 
new opportunities to challenge the structure and logic of the system. And governance units are the institutions charged with ensuring that the rules of the field are respected. The banking industry has manifold governance units at both the global level (Basel Agreement), the European Level (European Banking Authority, European Central Bank and others) and the member states' level (central banks). This is the case because fields are embedded in complex webs of other fields. At the micro level each individual bank is composed of several branches, and each branch of several departments or individuals. At the macro level, the banking industry of a country is made up of several banks, and at higher levels, such as the European Union, the banking industry is a strategic field comprising the sub-strategic fields of each country. The relationships between fields can be characterized as proximate-distant, vertical-horizontal and state-non state. Proximate fields are those with recurrent ties and whose actions routinely impact on each other, whilst distant fields are those with very few ties and whose action barely impact on the other. When relations between fields are vertical it means that one field exercises formal authority over the other. For instance, the European Union issues guidelines for the banking industry which member states' regulations must abide by. A horizontal relation between fields means that neither of them exercises formal authority but they mutually depend upon each other (for instance, the relationship between the central banks of France and Germany). Finally, as for the state-non state distinction it is important to bear in mind that "States (for us) are themselves dense collections of fields, whose relations can be described as either distant or proximate and, if proximate, can be characterized by horizontal or vertical links (...) on closer inspection states contain myriad social orders whose relations can be as conflictual and constraining as any other fields" (Fligstein \& McAdam, 2011:8). As we will see, this is specially the case for the banking industry: only the state has the ability to intervene and regulate. But "the State", in the case analyzed here, comprises several vertical levels (the EU, the member states), several horizontal levels (at the EU level several directorate generals can intervene in the banking industry) and the relations between all of them are usually conflictual.

Banking regulation is a phenomenon with two facets. On the one hand, it is a techno-scientific artefact. By applying the latest "scientific" advances in economics and finance, legislators try to produce a device that allows governments to control and monitor the behaviour of economic actors. 
From this point of view, an institutional regulation is an attempt to channel the course of events in such a way that political ends can be met. As clearly stated in the CRDIV the regulation of the banking sector in the EU aims to promote stronger financial entities and markets, and, ultimately, to enhance the economic well-being of the population. On the other hand, the regulation of a sector is also a problem of social equilibrium. As the Social Studies of Science (SSS) literature shows, technologies always occur in a given social milieu. Following the ideas posited by Latour (1992), before a scientific controversy is closed and turned into a black box upon which future scientists will base their work, fierce debates are held. Institutional regulation is always the product of social and political struggles, even when it is based mainly on expert knowledge provided by experts. The regulation of the banking industry has been reformed after the global financial crisis, with the implicit rationale that accurate knowledge of the causes of the crisis would permit policies to be designed to provide solutions and prevent future crises from occurring, or at least to limit their impact. This process started with the "De Larosière Report" (2009), continued with the creation of the European System of Financial Supervision in 2011, and in 2013 the CRDIV Directive was enacted. According to the diagnosis provided in the former directive, weaknesses in corporate governance contributed widely to the crisis. Bank managers had the wrong incentives and made risky decisions that contributed to the global financial and economic crisis. Therefore, the new legislation aims to impose certain conditions on the corporate governance of banks. Consequently, the current legislation (CRDIV, 2013/36/EU) includes a whole sub-sector (3) on governance. To exemplify how the banking industry might be studied using the strategic action approach, this paper will focus on the mechanisms that resulted in two controversial policies being implemented in the new legislation: diversity quotas and the State regulation of executives' remuneration policies. From the point of view of the policy-making mechanisms the paper will provide an overview of how banking is regulated in the EU. From the point of view of Social Studies of Science, the paper will try to shed some light on how such controversial issues as "What is the best way to govern a bank/an enterprise", which could require hundreds of pages of academic study are summarized in oneline policy prescriptions such as "banks should establish gender quotas in their boards." Current legislation has been heavily criticized, and questions have been raised about whether it will do the sector any good (Masera, 
2014; Stiglbauer \& Velte, 2015) and it has even been referred to as "quack corporate governance" (Enriques $\&$ Zetsche, 2015), implying that it was mainly enacted "for the sake of doing something". The paper will proceed as follows. First, an overview of the governance of the strategic action field of the banking industry will be provided, mainly at the European level but also at the global and national level. Second, the policy-making mechanism that resulted in the introduction of the aforementioned policies will be briefly analyzed. The paper will then conclude by singling out promising lines of research on the banking industry from the field of strategic action.

\section{The institutional regulation of the banking industry in the EU}

Understanding the banking industry as a strategic action field means realising that it is made up of several actors that know one other, and the purposes and rules of the field. The purpose of the field of the banking industry is to obtain an economic profit through the activities usually associated with financial entities. That is to say, lending money (mortgages, consumer credits, credits for entrepreneurs) accepting deposits and investing them, and providing financial services (credit cards, ATM, money transfers) for which they charge fees. As Masera (2014) stresses, the banking industry of the European Union is by far the world's biggest. This is due to the fact that enterprises are financed through the stock market (firms sell bonds) to a much greater extent in the US than in the EU, where firms mainly resort to banks when in need of financing. The activity of banks has always been State-regulated, because banks create money through the cash reserve ratio and can have a big impact on the economy. The amount of money banks must keep and cannot lend is therefore the main determinant of their activity and of how much money they can earn. The salience of the activity of the banking industry for the global economy became clear after the oil crisis of 1973. Once the Bretton Woods Agreements had been dismantled, the bankruptcy of an important German bank (Bankhauss Herstatt) led to considerable upheaval in the financial system at the global level. In order to cope with the perils of financial instability, the Basel Committee on Banking Supervision - BCBS) was created in 1974. Its main aim was to set a minimum on the requirements of capital banks should keep according to the risk they faced. It also issued general recommendations for the sound management of credit institutions, from then on known as "Basel I". And these recommendations, though not binding, were mostly adapted to national legislations. Since the Basel Committee on Banking 
Supervision was created several agreements have been entered into (Basel I, Basel II and, since 2010, Basel III) and the Basel Committee can be considered as the "Governance Unit" of the banking industry at the macro, global level, using the terms posited by Fligstein and MacAdam $(2011,2012)$

For countries belonging to the European Union the banking industry is regulated mostly at the European level. Since its very beginning, one of the main objectives of the European Union (then known as the European Economic Community) was to promote the creation of a single market for all European countries. Therefore, though legislation has varied over time, the current situation is that the vast majority of the regulation (field rules, as it is referred to in the theory of fields) takes place at the European level, and the member states adapt and transpose the European Directive and Regulation to their national laws. For example, in Spain Law 10/2014, of June 26, on Financial Institutions (Ley 10/2014, de 26 de junio, de ordenación, supervision y solvencia de las entidades de crédito) and the Royal Decree 84/2015, of February 13, adapt the European regulation, enacted in 2013. Considering the interconnections between European economies it is not surprising that financial services are mainly regulated for at the European level, because any significant difference in the way they are regulated would lead to unfair competition between member states. As mentioned above the main corpus of banking regulation in the EU is the so called CRD IV, which consists of one directive and one regulation. The CRD IV can be considered an adaption of the general "rules of the field" provided at the global level in Basel III Agreements, the recommendations for the sound management of financial entities issued in 2010, after the global financial crisis. However, the European and US regulations on financial institutions differ substantially in several domains, even though they both stem from Basel III, since the agreement permits considerable leeway. As summarized in the Memo provided on-line by the European Commission, the main aspects that European legislation adds to the Basel III general guidelines are the following: ${ }^{1}$ 1) Limitation of the variable component of the remuneration of risk takers (in order to avoid promoting excessive risk-taking by financial entities. 2) Introduction of new rules governing risk management by boards 3) Introduction of diversity quotas in the boards of financial entities (in particular, gender) 4) Enhanced transparency of the activities of financial institutions, in particular as regards profits, taxes and subsidies 5) Introduction of buffers

1The Memo can be found at: <http://europa.eu/rapid/press-release_MEMO-13-690_en.htm>. 
that enhance the percentage of cash financial institutions must keep to prevent bankruptcies from occurring.

How is the financial sector actually regulated in the EU? Who are the stakeholders consulted when a new regulation is drafted and how is the process driven? Participation in European elections and politics is relatively low in all member states, because citizens generally perceive the European Commission ("Europe") as a distant space of governance whose decisions do not interfere with everyday issues. Citizens tend to participate more in politics at the national level which, in turn, indirectly influences European policies. However, in the realm of finance, decisions that considerably influence everyday life are made in ways that remain obscure for the vast majority of standard European citizens. They might be extremely concerned about the interest rate and how it affects the monthly payment of their mortgages. Still, they have no idea how to influence the course of events. Therefore, we will now describe the process of policy making in Europe, specifically as regards banking regulation.

In the European Union the board entrusted with the responsibility of proposing legislation (such as the banking regulation analyzed herein) is the European Commission. With almost 34,000 members of staff, it is based mostly in Brussels (with some members in Luxembourg), and divided into departments - 33 as of late 2015 - called "directorate generals" (DGs) which can be compared to similar bodies in most western democracies (ministries in France, Spain or Italy, or departments in the USA). The European Commission is directed by the commission president (similar to a prime minister) and by the 33 "commissioners" (comparable to ministers, the head of each directorate general), appointed and elected by the European Parliament and the Council of the European Union, the two boards that form the legislature of the EU. The European Parliament, with 751 members is elected every five years on the basis of proportional representation. The plenary sessions are held in Brussels or Strasbourg and the administrative offices are in Luxemburg. The Council of the European Union, made up of 28 seats, represents the executive governments of the EU member states. The EU decision-making procedure involves the Commission having the initiative to propose new legislation. These proposals have to be approved by the European Parliament and the European Council. 
In principle each DG is in charge of a specific policy area. However, it is not uncommon for directorates general to overlap. For instance, in the field analyzed here, this is the case of at least the Directorate General "Economic and Financial Affairs (ECFIN)", and the Directorate General "Financial Stability, Financial Services and Capital Markets Union (FISMA)". The functioning of the European Commission combines political and technical steering. The political director of each directorate is its commissioner. Each member state is entitled to one commissioner. For instance, the Frenchman Pierre Moscovici is, as of October 2015, the commissioner of the Directorate General of Economic and Financial Affairs, Taxation and Customs, whilst the Jonathan Hill, from Britain, is the commissioner of the Directorate General of "Financial Stability, Financial Services and Capital Markets Union (FISMA)”. At every directorate general there is also a director general, who is its technical director (a civil servant). For the areas analyzed herein the Italian Marco Butti is the director general of ECFIN, and the Frenchman Olivier Guersent is the director general of FISMA. Each commissioner has a cabinet, consisting of several advisers, who focus on several policy areas. In a number of cases, deputy generals are in charge of several subareas. The policy mechanism of the European Union means that the European Commission proposes new legislation, but the European Parliament and Commission must debate and vote before it becomes law.

\section{A new banking regulation after the financial crisis}

Following the global financial crisis of 2008-2008, the European Union initiated a process to reform financial supervision, changing Directives 2006/48/EC and 2006/49/EC ('the Capital Requirements Directive' III) to prevent future crisis. The process started with the first meeting of the "High Level Group on Financial Supervision", chaired by Jacques de Larosière, ${ }^{2}$ in Brussels in November 2008, still a period of great financial turmoil. The group presented the conclusions, known as "The De Laroisere Report", in February 2009. The report was commissioned as a joint effort of the Directorate General of Economic and Financial Affairs (ECOFIN) and the Directorate General of Internal Market,

2 A former French civil servant, he was managing director of the International Monetary Fund (1978-1995) and of the Banque de France (1987-1993). From 1993 to 1998 he was the president of the European Bank for Reconstruction and Development. Since then he has been Chairman of the Strategic Committee of the French Treasury and Advisor to BNP Paribas. It is not surprising that one of the members of this High Level Group was Rainer Masera, an Italian ex minister and academic who published a paper in 2014 widely criticizing the new European Regulation. 
and it was followed by a consultation process. The first round of consultations for interested parties started as early as March 2009 (just a few weeks after the report had been submitted ${ }^{3}$ ). In May 2009 a Conference on a new supervisory architecture in Europe was held in Brussels. The European Commission made its first legislative proposals in September 2009. The first proposal was to set up a European Systemic Risk Board (ESRB), which was voted by the European Parliament and adopted by the European Council in the following year. The legislative texts were published in December 2010. These led to the adoption of macro prudential oversight of financial institutions as the main approach to this key issue (for macro prudential supervision see, for instance, Borio, 2003, 2011). As a consequence of this legislation three boards were created, the European Banking Authority (EBA, based in London), the European Securities and Markets Authority (ESMA, based in Paris), and The European Insurance and Occupational Pensions Authority (EIOPA, based in Frankfurt).

In February 2010 the European Commission launched a public consultation of stakeholders on changes in the Capital Requirement Directive, echoing the recommendations made by the G20 leaders in the summits held in London and Pittsburgh in 2009. ${ }^{4} \mathrm{~A}$ public hearing on this issue took place in Brussels in late April 2010. The following consultations concerned countercyclical buffers (October 2010) and counterparty credit risk (February 2011). Finally, in July 2011 as a joint effort by the Directorate General of Economic and Financial Affairs (ECFIN) and the Directorate General of Internal Market, Industry, Entrepreneurship and SMEs (GROW) the commission made a legislative proposal for a directive and a regulation of credit institutions. ${ }^{5}$ After some debate, in a Plenary Session of the European Parliament ${ }^{6}$ held in Strasbourg on 16 April 2013 the new proposal was adopted, and became EU law, as Directive and Regulation, in June 2013.

\section{The institutional regulation of Corporate Governance: a black box?}

\footnotetext{
3 The text of the consultation can be found at: <http://europa.eu//rapid/press-release_IP-09-373_ en.htm?locale $=$ en $>$.

4 The consultation can be found at <http://europa.eu/rapid/press-release_IP-10-197_en.htm?locale=en $>$. 5 The process can be followed at: <http://ec.europa.eu/finance/bank/regcapital/legislation-in-force/index en.htm>.

6 The Debate can be followed at <http://news-europa.eu/economy-finance-tax/item/53088-plenary-sessionof-the-european-parliament-joint-debate-capital-requirements-directive-crd-iv-strasbourg-16-april-2013>.
} 
According to the approach posited by Latour (1992) any technical or scientific controversy has two facets. Once a particular controversy has been solved it becomes "science", and provides certainty, answers and the foundations on which to build technical devices and enhance knowledge. But if the very same controversy is observed before it has been solved, there is no clue as to what the final answer will be, and rather than answers science seems to produce only new questions. From this point of view the regulation of financial institutions can be seen as a matter of scientific controversy. As mentioned above, the CRD IV Directive deals with key issues such as "how to better organize the remuneration of the members of banks' boards," or "what were the causes of the recent global financial crisis" as questions suitable for finding an unequivocal answer (as in classical "hard sciences"). Since the number of issues covered in this Directive clearly surpasses the possibilities and scope of this paper, from this point on we shall focus on only two issues: the remuneration policies of boards and their composition. These are two of the main additions made by European Legislation to the Basel guidelines, as stated by the European Commission itself in its online memo. ${ }^{7}$ What were the causes of the recent global financial crisis? In several points of its preamble the CRD IV Directive clearly states:

"(53) Weaknesses in corporate governance in a number of institutions have contributed to excessive and imprudent risk-taking in the banking sector which has led to the failure of individual institutions and systemic problems in Member States and globally".

“(60) The lack of monitoring by management bodies of management decisions is partly due to the phenomenon of groupthink. This phenomenon is, inter alia, caused by a lack of diversity in the composition of management bodies. To facilitate independent opinions and critical challenge, management bodies of institutions should therefore be sufficiently diverse as regards age, gender, geographical provenance and educational and professional background to present a variety of views and experiences (...)"

“(62) Remuneration policies which encourage excessive risk-taking behaviour can undermine sound and effective risk management of credit institutions and investment firms. (...) This Directive aims to implement international principles and standards at Union level by introducing an express obligation for credit institutions and investment firms to establish and maintain, for categories of staff whose professional activities have a material impact on the risk profile of credit institutions and investment firms, remuneration policies and practices that are consistent with effective risk management (...)."

7 As mentioned above, see: <http://europa.eu/rapid/press-release_MEMO-13-690_en.htm>. 
"(65) (...) in order to avoid excessive risk taking, a maximum ratio between the fixed and the variable component of the total remuneration should be set. It is appropriate to provide for a certain role for the shareholders, owners or members of institutions in that respect. Member States should be able to set stricter requirements as regards the relationship between the fixed and the variable components of the total remuneration. (...)"

"(66) In order to ensure that the design of remuneration policies is integrated in the risk management of the institution, the management body should adopt and periodically review the remuneration policies in place. The provisions of this Directive on remuneration should reflect differences between different types of institutions in a proportionate manner, taking into account their size, internal organization and the nature, scope and complexity of their activities. In particular it would not be proportionate to require certain types of investment firms to comply with all of those principles".

To sum all this up, the diagnosis provided in the Directive as regards the issues analyzed herein is that the global financial crisis (at least in its manifestation in Europe) had to do with 1) weaknesses in corporate governance 2) group thinking behaviours, caused by lack of diversity in the executive boards of financial institutions and 3) remuneration policies that encouraged unsound risk-taking. These solutions to the scientific controversy over what caused the crisis are now part of legislation enclosed in a black box (using Latour's term). And it is from this diagnosis of the causes of the crisis that policies are designed to tackle them, and a whole subsection (3) is devoted to the governance of credit institutions. To prevent weaknesses in corporate governance causing future problems to the financial system, article 91 of the directive (Management body) states: "Members of the management body shall at all times be of sufficiently good repute and possess sufficient knowledge, skills and experience to perform their duties." And the task of issuing guidelines about what all this can mean is entrusted to the European Banking Agency (EBA).

To cope with the problems of group thinking article 88 (Governance arrangements) says: "Member States shall ensure that the management body defines, oversees and is accountable for the implementation of the governance arrangements that ensure effective and prudent management of an institution (...) The nomination committee shall identify and recommend, for the approval of the management body $(. .$.$) candidates to$

8 The full text of the Directive can be found on line at <http://eur-lex.europa.eu/legal-content/EN/TXT/ HTML/?uri=CELEX:32013L0036\&from $=\mathrm{EN}>$. 
fill management body vacancies, evaluate the balance of knowledge, skills, diversity and experience of the management body (...). Furthermore, the nomination committee shall decide on a target for the representation of the underrepresented gender in the management body and prepare a policy on how to increase the number of the underrepresented gender in the management body in order to meet that target. Finally, to tackle the problems caused by bad remuneration policies giving the wrong incentives, articles 92 (remuneration policies) and 94 (variable elements of the remuneration) set the bar. In particular, article 94 states: "For variable elements of remuneration, the following principles shall apply in addition to, and under the same conditions as, those set out in Article 92." Point (g) of this article says: "Institutions shall set the appropriate ratios between the fixed and the variable component of the total remuneration, whereby the following principles shall apply: (i) the variable component shall not exceed $100 \%$ of the fixed component of the total remuneration for each individual. Member States may set a lower maximum percentage."

These are the answers the regulation (CRDIV) gives to the questions about what the causes of the crisis were and how credit institutions should be managed to improve their situations. But, to what extent are the answers that have been given to such thorny issues pristine and clear? On what basis has the "scientific" controversy been closed? If we look at the Commission proposal for a Directive issued in July 2011, ${ }^{9}$ which was the text taken as the basis for debate, some clues about the "scientific" method used to find the answers can be found. Point 1.2 .2 of the explanatory memorandum says: "In its Communication of 4 March 2009 the European Commission announced that it would examine corporate governance rules and practice within financial institutions in the light of the financial crisis (...) In June 2010, the Commission published a Green Paper on corporate governance in financial institutions and remuneration policies and an accompanying staff working document which analyzed the deficiencies in corporate governance arrangements in the financial services industry and proposed possible ways forward. The results of this public consultation demonstrated a broad consensus on the deficiencies identified, receiving support from different public authorities and Member States." How was this broad consensus reached? Point 2.1.2 of this proposal, on Corporate

9 The full text of the proposal can be found on line at <http://eur-lex.europa.eu/legal-content/EN/TXT/ HTML/?uri=CELEX:52011PC0453\&from =EN>. 
Governance, provides the "methods" of the study that was carried out to answer these questions:

The initiative and impact assessment is the result of an extensive and continuous dialogue and consultation with all major stakeholders, including securities regulators, market participants (issuers, intermediaries and investors), and consumers. Questionnaires on their corporate governance practices were sent to a diverse cross-section of 10 major listed banks or insurance companies established in the EU. The questionnaires were augmented by 30 follow-up interviews with Board members, company secretaries, chief financial officers, chief risk officers, internal controllers. A questionnaire on their views and role regarding corporate governance of financial institutions was also sent to the European banking supervisors. Similarly, a cross-section of major European institutional investors and shareholders' associations received a questionnaire on their practices and expectations regarding corporate governance of financial institutions. A follow-up meeting with about 30 investors was held on 2 February 2010. The Green Paper finally launched a public consultation from 2 June 2010 to 1st September 2010 on the possible ways forward to deal with failures in corporate governance in financial institutions. The responses and their analysis can be consulted on the Commission website

The transparency criteria implemented by the EU institutions implies that there is sufficient information available on-line about the various consultation processes that took place before the enactment of the new legislation. However, this brief overview of the actual "study method" would certainly make any academic in the fields of Organizational Theory or Sociology of Organizations blush. The "research method" used to define the "best practices" included a sample of only 10 major banks or insurance companies, and only 30 individuals were interviewed. It goes almost without saying that the views of these respondents have had a disproportionate effect on the final regulation as regards their share of the actual "population" of the European Banking Industry (in the debate held in the European Parliament in 2011 on this proposal it was stressed that at the time there were some 8,300 banks in the EU). The approach of the Social Studies of Science stresses that it is impossible to make a clearcut distinction about whether a controversy is only technical or whether it is political. From this point of view, we believe that a study of the banking regulation resulting from that approach seems most fruitful. As mentioned above, prior and post to the enactment of the legislation several academics have written papers that question the "conclusions" of this study 
on which the legislation is based (see, for instance, Masera, 2014; Enriques and Zetsche, 2015; Stiglbauer and Velte, 2012, among others). But furthermore, leaving aside the "methodological" issues (the sample could be considered to be biased) the respondents in this study have some sort of connection to the institutions that carried it out. Therefore, according to the theory of fields, they can be considered to be "incumbents". We will now proceed to make some remarks about the evolution of the banking regulation in the EU following this approach.

The final result of the regulation of the banking industry can be better understood if we consider the industry as a strategic action field, which is itself made up of several strategic action fields. As a working hypothesis we propose analyzing the industry at three levels: global, European and national. Even though there are differences in power among the different actors, these differences are not static, and actors act strategically to improve their position within the field. According to the approach posited by Fligstein and McAdam (2011:7) this has to do with social skill: that is to say, how actors (in this case collective actors) frame their lines of action, mobilize people and use their cognitive capacity for reading people and environments. In this regard the recent evolution of the banking industry has been quite different in the various European Countries. For instance, in the case of Spain (see, for instance Santana Turégano and Rodríguez González, 2015), between the 1980s and 2005 the savings bank sector grew significantly, but has since then virtually disappeared. After the crisis of 2008 the Spanish financial system, formerly made up of around 45 institutions was reduced to only 15 major banks. The evolution has been quite different for the French and German cases, where credit unions and savings banks have remained important.

The evolution of the banking industry in each Member State is of course embedded in the broader field. The evolution of European regulation has permitted major players in a country to carry out their activity in other countries, and therefore, according to the founding principles of the EU, the market for financial services has been at least partially unified. Under the current situation, the biggest banks (incumbents) operate in the vast majority of European markets, or at least in the main ones, in a variety of different ways. ${ }^{10}$ Some banks still remain important in their home markets

10 For instance, in some cases a bank originally from one country is currently present in many countries of the UE under the same denomination (Deuthsche Bank or Barclays, for example, are also present overseas). In other cases, the denomination of the banks varies slightly (for instance, the Spanish Banco de Santander is "Banco de Santander-Totta" in Portugal, and operates as "Santander" in the UK and similar brands in other European countries.) 
even though their presence in other countries is much smaller. The global financial crisis of 2008 can be considered an "episode of contention", where field participants had a shared sense of uncertainty regarding the rules and power relations in the field (Fligstein and McAdam, 2011:9). However, the mobilization has not been equal among incumbents and challengers, because the "rules of the fields" strongly favoured the major banks. The recent reconfiguration of the regulation of the banking industry has transferred much of the regulation from the national (Member States) to the EU level. The bigger banks, which were already present in the biggest markets in the EU, had a disproportionate influence on the regulation. As mentioned above, when the new legislation was drafted only 10 major banks out of the 8,300 banks in the UE were consulted. It is not surprising then that this period of crisis has been settled in a way in which the State, in this case the European Union, has been the focus in action (Fligstein and McAdam's proposition 14 on settlement) and the field has been transformed in a such a way that only major banks can be competitive under the new rules of the field, as critics of the new regulation have pointed out (Enriques and Zetsche, 2015)

\section{Conclusions: a research agenda}

The aim of this paper was to shed some light on the regulation of the obscure and opaque field of finance, traditionally a domain about which only the opinions of experts should be considered. We have pointed out how some of the controversies that have been "scientifically overcome" are in fact the result of social equilibria that may well change in the future. The debate in the European Parliament on the approval of the CRD IV gives some illustrative examples. Some Mr Bloom (European Freedom and Democracy, UK) considered the new legislation (CRDIV) to be "the triumph of hope over experience." He considered that the situation was a flawed banking system, where bankers can lend money which they do not have, but that a great deal of regulation was the wrong type and that the real issues had not been solved with the proposed legislation. ${ }^{11}$ " From this initial approach we believe two lines of research might prove fruitful, not only to advance knowledge about the banking industry but, at the theoretical level, to better understand how strategic action fields and expert-technocratic systems work.

From the point of view of strategic action fields, this line of research could follow a long tradition of research that works with network analysis.

11 The whole debate can be found at the aforementioned link. 
As mentioned above, the process of reform of the European Regulation was initiated by a former International Monetary Fund president. The European Union provides significant information about the biography and $\mathrm{CV}$ of both political (commissioners) and technical (director general) positions. Therefore, the hypotheses that generally inform the public debate, such as the "revolving doors" and how "incumbents" are able to shape the rules of the fields in ways that best suit their interests, could be empirically proven (or not). To further enhance the knowledge of financial regulation using the theory of strategic action fields would require deepening the understanding of the social skills involved, the incumbents and challengers and the governance units. The CRD IV certainly laid down new rules that changed the social equilibria in the field. How can they shape the future world? Even though this paper can only add a very humble grain of sand to the vast task of finding what, in the tradition posited by Portes (1999), can be called "the hidden abode" - that is to say, how the hidden causes of social behaviour can be unveiled - we believe that these issues are the ones without which the Social Sciences could not accomplish their long standing tradition of helping to understand and shape the social world. We will now indicate what we think might be promising avenues for future research.

According to Enriques and Zetsche (2015:240) three groups emerge as winners after the new regulation of the banking industry: consultants, politicians and policy makers, and bank supervisors. First, many of the new provisions will make it difficult for smaller banks to have the skills and experience required, and they will quite likely resort to external consultants to cope with the new demands. What social skills were involved in the process? Since much of the regulation is currently at the European Level, international consultancy firms with branches in different countries might become "incumbents", since their capacity to influence the rules of the field have been enhanced. Second, another result of the new regulation, as pointed out by the authors mentioned above, is that politicians can now present themselves as having done a lot to restore trust and thus gain (or regain) public confidence. Finally, bank supervisors have gained a wide range of regulatory and supervisory power over bank boards, and a few individuals in a few strategic places can have such influence on individuals and institutions that they might be considered to be a "government at a distance" (Izquierdo, 2002). Taking all this into account, it seems that an 
analysis of how these three actors with different roles are connected will be a fruitful line of research.

From the point of view of the social studies of science, it is almost paradoxical that the very phenomenon that the regulation was trying to tackle (group thinking) might actually have informed the legislation. A quick review of the CVs shows that many of the significant players in the field have similar educational backgrounds. Therefore, consensus might not be so much a clear, unequivocal diagnosis of the causes of the crisis and its remedies but the result of shared common points of view. In a recent paper by Borio (2013), an author who is often regarded as one of the pioneers of the concept, stresses that the idea of "macro prudential regulation", developed in the meetings of the International Bank of Settlements in the late 1970s, was for a long time only familiar to a small circle of cognoscenti and has lately become a common token in policymaking. How are these types of consensus developed?

As a consequence of the growing interest in financial regulation Wymeersch, Hopt and Ferrarini published a book on the issue in 2012 (Wymeersch, Hopt, and Ferrarini, 2012). The experts' opinion on the likely effect of the regulation (the scientific controversy) was quite negative. Winter's analysis (Winter, 2012) indicated that it seemed difficult (if not impossible) to remedy governance problems in financial institutions through regulation. And more precisely, the idea that the financial crisis was a consequence of weaknesses in corporate governance Hopt (2012) stated that "whether failures in the corporate governance of banks were a major cause of the financial crisis is highly controversial". How has this "scientific uncertainty" been turned into "policy making-certainty"? Black (2012) gives some insightful comments about why regulators are somehow allergic to publicly acknowledging the difficulty of making clear policies: "Regulators have to engage in processes of critical self-reflection if they are to learn, but in so doing they risk jeopardizing their claim to expert authority. Leaders and experts are expected to know the answers. To be constantly questioning what one is doing can look to outsiders as if one is trapped in self-doubt (...) Admitting to mistakes can therefore be self-undermining." The traditional solution to this problem, as Black puts it, has been that regulators claim that they are simply implementing decisions made elsewhere. In this regard, the development of the whole body of European policies has provided considerable leeway for legislators at the European, national (member states) and infra national (regions) 
levels. The claims to expert authority seem easier to maintain in a situation in which it is always possible to maintain publicly that policies are merely technical, the implementation of decisions made elsewhere on the basis of expert knowledge which always remain obscure. How scientific is the Economic Science on which many economic policies base their legitimacy? Regulation based upon "expert knowledge" is becoming more and more a key issue in many spheres of social life, not only in the domain of financial regulation, and not only in the European Union. From drug regulations to the management of the fiscal deficit, more and more decisions are being legitimized by resorting to "science". Therefore, even though it goes well beyond the aims and scope of this brief enquiry, we believe that combining the theory of action fields and the social studies of science seems a fruitful and promising avenue to further enhance the knowledge of the complex social world in which we live.

\section{References}

BLACK, J. (2012). «Restructuring global and EU financial regulation: character, capacities and learning» in Wymeersch, E; Hopt, K. J. and Ferrarini, G. (eds). Financial Regulation and Supervision, A post-crisis analysis, Oxford, Oxford University

Borio, C. (2003). «Towards a macroprudential framework for financial supervision and regulation?». BIS Working Papers, n 129, Basel, Basel Bank for International Settlements).

Borio, C. (2011). «Implementing a Macroprudential Framework: Blending Boldness and Realism». Capitalism and Society, Vol. 6, Issue 1, Article 1, 2011. Available at SSRN: <http://ssrn.com/abstract $=2208643>$.

Enriques, L. and Zetsche, D. (2015). "Quack corporate governance, Round III? Bank board regulation under the New European Capital Requirement», Theoretical Enquiries in Law, 16-1.

Fligstein, N., and McAdam, D. (2011). «Toward a general theory of strategic action fields». Sociological theory, 29(1), 1-26.

Fligstein, N., and McAdam, D. (2012). A theory of fields. Oxford: Oxford University Press.

Норт, K. J. (2012)+ «Corporate Governance of Banks after the Financial Crisis» in Wymeersch, E; Норt, K. J. and Ferrarini, G (eds). Financial Regulation and Supervision, A post-crisis analysis, Oxford, Oxford University 
Izquierdo, A. J. (2002). «De la fiabilidad. Riesgo financiero y gobierno a distancia», en A. Rubio (ed.), Finanzas y sociedad, Madrid, Paraninfo, 337 368.

Latour, B. (1992). Ciencia en acción, Barcelona: Labor.

Masera, R. (2014). «CRR/CRD IV: the trees and the forest». PSL Quarterly Review, vol 67, 271, 381-422.

Portes, A. (2000)+ «The hidden abode: Sociology as analysis of the unexpected». American Sociological Review, 65(1), 1-18.

Santana Turégano, M. and Rodríguez González, P. (2015). «Fictional expectations in economic organizations. A case study in the banking industry». Revista Española de Sociología, 24: 9-23.

Stiglbauer, M. and Velte, P. (2012). «The economic versus moral perspective of board diversity: a time for regulation after the financial crisis?» The International Journal of Organizational Diversity, Vol 12.

Wymeersch, E; Нopt, K. J. and Ferrarini, G. (eds) (2012). Financial Regulation and Supervision, A post-crisis analysis, Oxford, Oxford University.

\section{Acknowledgments:}

The author wishes to acknowledge Juan Pablo Pardo-Guerra and Daniel Beunza, from the London School of Economics (LSE). Juan Pablo gave me the idea of analyzing the information available on line about the CRD IV as data for research. Daniel pointed me in the direction of Latour's work and the Social Studies of Science approach as a way of understanding banking regulations, a field that at that point in time was quite opaque to me. Of course, all errors are my own. 